\title{
Albanian Economic Policies on Foreign Direct Investments during 1990-2009
}

\author{
Ilirjana Zyberi \\ University "Eqrem Çabej"of Gjirokastra, Albania \\ Email: izyberi@yahoo.com \\ Klodian Muço \\ University "Eqrem Çabej"of Gjirokastra, Albania \\ Email: klodianmuco@hotmail.com \\ Lindita Rova \\ University "Eqrem Çabej"of Gjirokastra, Albania \\ Email: lindita_rova@yahoo.com
}

Doi:10.5901/mjss.2015.v6n3p289

\section{Abstract}

Attracting FDI is top priority to Albania not only to finance its budgets, but moreover to improve the economic development and standard of living. High inflow of FDI can increase efficiency of the production and introduce new products on the markets. Experience has shown that foreign direct investment has had a major impact on the economic growth of a country. Some of these benefits are: a) increase in competitive potential between domestic production enterprises. b) the entrance of advanced technology c) progress in knowledge of various fields of production resulting from contacts with foreign customers d) possibilities for the optimal utilization of human resources and help to increase their professional skills etc. In this paper we will analyze FDI on a national introducing three models: the first model is going to analyse the monetary policies, then fiscal policies and in the end we are going to take into consideration all the figures on a national scale taking into account the corruption, as well. We will confirm the important role of the monetary and fiscal policy to attract foreign investments in Albania aiming to serve the economic growth. Based on economic results, we easily observe the dependency of foreign investments on profit tax, on immigrants' shares, on interest norm and on the monetary aggregate M3. The most unexpected result is that no important index exists between FDI and corruption.

Keywords: foreign direct investments, fiscal policies, monetary policies, GDP;

\section{Introduction}

The ability to attract foreign direct investments (FDI) has become, the last decade a focal point of the economic policies of many developing countries. This strategy is based on the view that FDI flows increase the production potential of the country and of course the productivity level. Furthermore it assumed that the foreign capital can play a deep role in simulating local investments activity, both upstream and of the production chain and also in the acquisition level, in the development and the dissemination of technology. In line with these considerations, there has been a steady increase in the weight of developing countries on global FDI flows, interrupted only during the period 1997-2000, following the spread of the Asian crisis. In this context the Mediterranean area is highlighted for its weak performance, both on worldwide and also within the developing countries. In fact, while in the last decade, the rate growth of FDI in the world has been steady and very strong, and in particular those directed to developing countries, the Mediterranean countries appear to have remained at the edge of such processes. Albanian FDI level remains a major problem since the advent of Albanian democracy; their flow in recent years has just surpassed the 30 million dollars annually, ranking the country among the last places in Europe of attracting FDI. Few years ago the Democratic Prime Minister Berisha during a cabinet meeting appeared elated to present the solution. He baptized "Albania-1euro" his initiative to make the country more attractive to the foreign investors. Despite this Albania doesn't looks like an attractive country to foreign investments for a number of reasons:

- Strong institutional weaknesses (inefficiency and bureaucracy)

- Corruption, 
- The uncertainty of the transaction rules for foreigners (e.g. property rights)

- Infrastructure and networks problems

- The delay in the process of privatization of many sectors of the economy etc.

\section{Empirical Analysis}

To serve this study, we are going to draw the official information from these institutional sources:

- Ministry of Finance

- Directorate General of Taxes

- Central Bank of Albania

- Ministry of Economy

- INSTAT Albania

Simultaneously, we are going to make use of studies performed by the International Monetary Fund, European Bank for Reconstruction and Development as well as other International Institutions.

To serve our empirical analysis, we are going to use two data groups; data taken from INSTAT and information drawn from the Directorate General of Taxes. At the same time, we are going to develop the same econometric model using information from the above mentioned international institutions. Furthermore, we are going to analyse the fiscal incomes of 1990-2009, the flow of foreign investments for the same period and the economic indicator.

Greater importance will be shown to:

- Year-round fiscal incomes paying more attention to those years of fiscal reforms with new taxes.

- Fluctuation along with the flow of Foreign Investments in Albania (FDI) (or precisely the increase of fluctuation after the fiscal reforms have been made at the same time), as well as the foreign investments regionally based for the same period of time.

- The rate of economic growth (GDP) in Albania after the change of political system from the existing collective system being exercised during the communist period, where everything belonged to people.

- The newly democratic system accompanied by mass privatizations and the birth of private property.

- Simultaneously, we are going to take into consideration the standard fluctuation such as: import, export, and the increase of GDP, the immigrants' savings, the norm of interest for investments and the norm of interest for savings.

- The monetary aggregates M1, M2, M3 to understand how short-termed and long-termed monetary policies influence the flow of foreign investments, being also based on the figures of inflation and the corruption level.

The data drawn from INSTAT and the governmental institutions of the Albanian state have continuously had a series of wrong values. This pattern has been followed by all the Albanian governments taken into consideration to improve their performance during the electoral elections as well as to grow the credibility in the face of international institutions regarding the obligations they pretend towards reforms. To eliminate the inaccuracy in elaborating the following information, we will correct no data of INSTAT or The Directorate General of Taxes but we will compare them with those data drawn from the International Institutions.

The greater part of them is taken from the International Institutions such as: World Bank, International Monetary Fund, and International Transparency Agency. In order to realize an empirical analyse at the following models, we also based ourselves on data having been elaborated by authors. Unfortunately, information on regional unemployment is accurate only for years 2002, 2003 published from INSTAT, and for the years 2007, 2008 published by the Ministry of Work, Social Affairs and Equal Opportunities. Regarding other years, we are going to consider the average number of unemployment for all the regional municipalities.

The fiscal system of the Republic of Albania underwent an entire reform during the period 1990-2009. Worth mentioning are the most crucial reforms of 1992, 1996, 1999, 2005 and 2008. Their results are felt a year after the implementation. Worth mentioning is also the increase of FDI flow excluding here the reform of 1996 which was slightly felt because of 1997 when we experienced the financial Albanian decline because of the financial pyramids invented by Carlo Ponzi.

The financial reform of 2008 aimed at tempting the foreign investors to transform Albania into an attractive country for foreign investments. This reform came to fruition and we can observe it at the graph nr 1.1. It shows the level of Foreign Direct Investments in Albania from 1990 to 2009. Based on the data analysis, we notice that the tendency of FDI goes up in a swing with the culminating point the years 2008-2009 (we should underline that this tendency is due to mass privatizations committed by the government of Berisha and not to the willingness of foreign investors to invest in our 
country).

Chart 1.1: Flow of foreign investments in Albania during 1990-2009 (million euro)

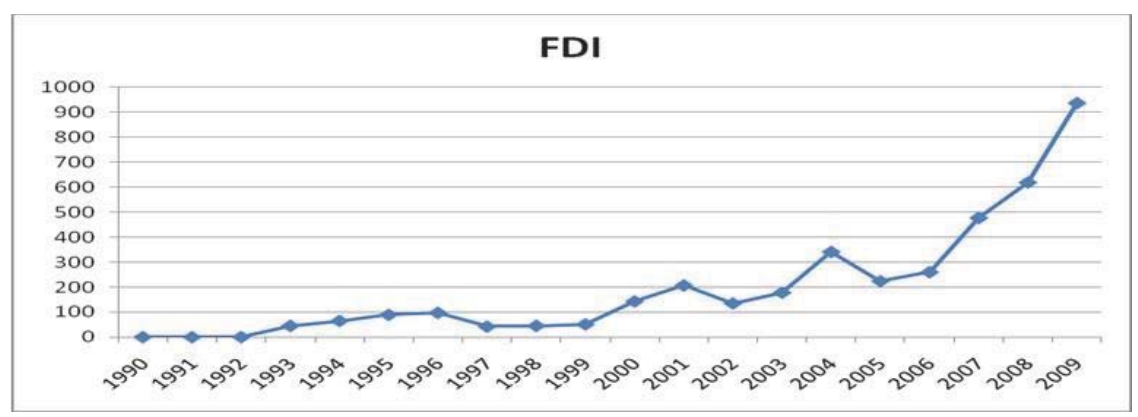

Source: IMF, WB and ITA

\subsection{General Administrative data}

Albania consists of 12 Regions. Each region is composed of 3 categorized Municipalities where one of them belongs to the regional centre. Information drawn at the region is not so reliable because we have simply available data taken from the Albanian institutions and not from International Institutions. The information related to regional FDI is elaborated data not $100 \%$ accurate. Viewing these data, it is noticed a higher concentration of FDI in Tirana, the capital city of Albania with a population of more than 800 thousand inhabitants. Meanwhile, we notice a concentration of FDI along the coastal and border towns like Durrësi and Vlora. In the following econometric models we will try to make use of all the available data. The first problem being faced is the lack of information in 1997 because of the reason stated above. We hold the opinion that it is more efficient to present 2 model groups. In the first group we are going to make use of information on a national scale, available for the majority of International Institutions. While in the second group, we are going to mainly use regional information, available in the greater part only by Albanian Institutions.

\section{The Factors Determining the Flow of Foreing Investments in Albania}

To estimate the effect of FDI on a regional scale, we will consider: the flow of FDI, the population, the unemployment and the flow of FDI per person. In order to make use of all the data altogether, we are going to launch our study on the correlations between these varieties.

Table.1.1. The coefficient of correlation, using observer 1:001 - 2:120, Critical value5\% (per twice) $=0,1267$ per $n=240$

\begin{tabular}{|c|c|c|c|c|}
\hline FDI_per_Region & N_Unempl_Region & FDI_P_Per_Region & Pop_per_Region & \\
\hline 1,0000 & 0,0225 & 0,8598 & 0,1488 & FDI_per_Region \\
\hline 0,0225 & 1,0000 & 0,1446 & $-0,2594$ & N_Unempl Region \\
\hline 0,8598 & 0,1446 & 1,0000 & $-0,1036$ & FDI P per_Region \\
\hline 0,1488 & $-0,2594$ & $-0,1036$ & 1,0000 & Pop_per_Region \\
\hline
\end{tabular}

The matrix of correlation points out a good figure of correlation between the parameters of unemployment and FDI on a regional scale, precisely a negative correlation between unemployment and FDI on a regional scale. It is therefore the negative correlation which allows us to follow such parameters on the same regression model.

\subsection{The first model.}

$$
F D I_{\text {per }_{\text {region }}}=\alpha+\beta_{1} \text { Pop }_{\text {per }_{\text {region }}}+\beta_{2} N_{\text {unempl }_{\text {Region }}}+\beta_{3} F D I_{P_{\text {per Region }}}+\beta_{4} E x p+\beta_{5} G D P_{\text {per }_{\text {pers }}}+\varepsilon
$$

Let's mark with a distance from the main cities being a statistic variable which does not change in relation with time, $\varepsilon$ is the term of mistake, $\beta_{1}, \beta_{2}, \beta_{3}, \beta_{4}, \beta_{5}$ are the coefficients of the model. 


\section{Table 1.2}

\begin{tabular}{|c|c|c|c|c|}
\hline \multicolumn{5}{|c|}{$\begin{array}{l}\text { Model 1: Occasional effects (OLS), based on } 240 \text { observations. } \\
\text { Including } 12 \text { units cross section } \\
\text { The length of historical series = } 20 \\
\text { Depending variable : FDI_PER_REGION }\end{array}$} \\
\hline & Coefficient & Standard mistake & Report $t$ & $p$-value \\
\hline Constant & $-11,873$ & 12,2983 & $-0,9658$ & 0,3352 \\
\hline Pop_per_Region & $3,36756 \mathrm{e}-05$ & $1,64485 e-05$ & 2,047 & $0,0418^{* *}$ \\
\hline N_Unempl_Region & $-0,203455$ & 0,172886 & $-1,177$ & 0,2405 \\
\hline FDI_P_Per_Region & 117639 & 4194,41 & 28,05 & $3,56 e-076^{* * *}$ \\
\hline Dis_Dr & $-0,0371027$ & 0,0870231 & $-0,4264$ & 0,6702 \\
\hline Dis_Tr & 0,0768883 & 0,0870073 & 0,8837 & 0,3778 \\
\hline Dis_VI & $-0,0176679$ & 0,0568452 & $-0,3108$ & 0,7562 \\
\hline Dis_Gj & 0,0219237 & 0,0408072 & 0,5373 & 0,5916 \\
\hline GDP_Per_Pers & $-360,283$ & 81,3661 & $-4,428$ & $1,47 e-05^{* * *}$ \\
\hline Export & 0,000329108 & $5,40153 e-05$ & 6,093 & $4,63 e-09^{* * *}$ \\
\hline
\end{tabular}

Generally viewed, the first model shows an important result. The depending parameters of FDI on a regional scale are clearly illustrated by the GDP variable per person ( $p$-value: 1,47e-05). Other important figures are the export ( $p$ - value: 4,63e-09) and the population parameters on a regional scale ( $p$-value: 0,0418 ).

GDP per person and the export parameters are an easy example to interpret. FDI per region gives a considerable contribution to the increase of GDP and the export diagram. It means that a considerable part of FDI in Albania are addressed to only transfer the process of production (thus, to exploit the cheap labour of the working class) and afterwards they export the readymade product to the original country where they have first set up and initiated their business and operation. At the same time, we could emphasise that the product being produced in Albania is not destined for the Albanian market.

The unexpected result of the first model gives us the impression that the geographic position where FDI is addressed is not an important factor. This result can be explained on the basis of the model we used. It was an OLS model with occasional effects bearing in mind that the distance is constant when it is perfectly surveyed by this model. If we try to have the same model OLS, not with occasional effects but with continuous ones, we notice that we get higher figures which are excused (as we already mentioned about export); it can also be explained by the reason that the Albanian state has its main commercial partners Italy and Greece, therefore those border countries which transfer in Albania only a part of their production process (the clothing industry).

\subsubsection{Divergent determining possibilities of FDI in Albania during 1990 until 2009}

We observe heterogeneity in distributing FDI to many regions. There has been a noticeable concentration of FDI in Tirana. It is because of its population which is more than 800.000 inhabitants, which means a better and wider market for public consumption. As being mentioned above, the geographical position plays a strategic and important role. The Albanian borders, especially the coastal ones play a decisive factor to the economic growth. We have a dense concentration along the border and coast. As we mentioned above, FDI is addressed to Albania mainly to exploit the low cost of the working class and the Albanian fiscal system which is profitable especially for the first three years of activity. ${ }^{1}$ We also observe not an important correlation (despite the negative sign) between the norm of unemployment and FDI on a regional scale. It is because of the fact that a part of FDI have not been greenfield ones but investments on purchasing and developing the existing businesses. It goes without saying that employment has not always been on the increase, despite the high level of FDI.

Model 2 is the same with the first with the only exception that in this case the estimation is made by OLS Pooled taken as a depending variable of national FDI.

$$
F D I_{\text {per }_{\text {region }}}=\alpha+\beta_{1} \text { Pop }_{\text {per region }}+\beta_{2} N_{\text {unempl }_{\text {Region }}}+\beta_{3} F D I_{P_{\text {peregegion }}}+\beta_{4} E x p+\beta_{5} G D P_{\text {per }_{\text {pes }}}+\varepsilon
$$


Table 1.3. The result and the number of observations followed at model 2

\begin{tabular}{|c|c|c|c|c|}
\hline \multicolumn{5}{|c|}{$\begin{array}{l}\text { Model 2: Pooled OLS, based on } 240 \text { observations. } \\
\text { Including } 12 \text { units cross section } \\
\text { The length of historical series = } 20 \\
\text { Depending variable : FDI }\end{array}$} \\
\hline & coefficient & Standard mistake & Report t & $p$-value \\
\hline constant & $-49,4083$ & 41,4774 & $-1,191$ & 0,8830 \\
\hline Pop_per_Region & $-8,08019 e-06$ & $5,48500 \mathrm{e}-05$ & $-0,1473$ & 0,0418 ** \\
\hline N_Unempl_Region & $-3,65747$ & 0,895623 & $-4,084$ & $6,11 \mathrm{e}-05$ *** \\
\hline FDI_P_Per_Region & 46884,3 & 22778,7 & 2,058 & 0,0407 ** \\
\hline $\bar{D}$ Dis_Dr & $-0,0726466$ & 0,308103 & $-0,2358$ & 0,8138 \\
\hline Dis_Tr & 0,123060 & 0,297941 & 0,4130 & 0,6800 \\
\hline Dis_VI & 0,0206406 & 0,194432 & 0,1062 & 0,9155 \\
\hline Dis_Gj & 0,111945 & 0,140999 & 0,7939 & 0,4280 \\
\hline GDP_Per_Pers & $-360,283$ & 81,3661 & $-4,428$ & $1,47 \mathrm{e}-05$ *** \\
\hline Export & 0,00606005 & 0,000198254 & 30,57 & $3,88 \mathrm{e}-083$ *** \\
\hline R-current & 0,827874 & \multicolumn{2}{|c|}{ R-current frame } & 0,821912 \\
\hline Test F & $F(8,231)$ & \multicolumn{2}{|c|}{ P-value(F) } & $8,48 e-84$ \\
\hline
\end{tabular}

Stimulating OLS pooled, following the same parameters except the change of the depending variable which is moved from regional FDI to national FDI. The results are practically the same with the first model. Even though we encourage a panel with sustainable effects, the same results are given regarding the geographical position, but knowing that this model might not be $100 \%$ efficient and econometrically accurate because all variables are dynamic in time and meanwhile we are given prevailing data drawn from Albanian Institutions.

We would not like to comment the results of this model, we would like simply to observe if it were any difference when we moved from regional FDI to national FDI. Possessing the results drawn from the first two models mentioned above, they provide confirmation of all the hypothesis made by International Institutions ${ }^{1}$ as well as by many articles published by the Albanian Agency of Investments (Albinvest) ${ }^{2}$. In conclusion, we could point out that it is being invested in Albania with the mere goal to reduce the production costs, despite being a small country with a limited market.

\subsubsection{The decisive factors of FDI in Albania}

To analyse FDI on a national scale and to verify the results of different international reports, such as Doing Business of World Bank or Albanian New Investments Strategy and International Monetary Fund, we are going to introduce three models.

The first model is going to analyse the monetary policies, then fiscal policies and in the end we are going to take into consideration all the figures on a national scale taking into account the corruption, as well. At the first model, we will use as depending variable FDI and as other variables we will consider the monetary policy: GDP, the free international market (The report of export and import depending on GDP), the immigration incomes, and the norm of inflation, the norm of interest, the exchange rate, and the monetary aggregate and last but not the least corruption.

\subsection{FDI and the monetary policy}

Based on international reports and the policies of the Bank of Albania, we could say that Albania is not the exact matured country regarding the commitment of monetary policies.

We will be guided by a simple model as follows:

$$
F D I=\alpha+\beta_{1} N_{\text {Exchange }_{\text {interes }}}+\beta_{2} N_{\text {Int fin }_{\text {fin }}}+\beta_{3} E_{\text {rate }} \frac{L}{\$}+\beta_{4} E_{\text {rate }} \frac{L}{\text { euro }}+\beta_{5} \text { Immigrant }_{\text {incomes }}+\beta_{6} A_{g r_{M 3}}+\varepsilon
$$


Table. 1.4

\begin{tabular}{|l|c|c|c|c|}
\hline \multicolumn{5}{|c|}{ Model 3: OLS, based on observations. 1990-2009 (T = 20) } \\
Depending variable FDI \\
\hline & coefficient & Standard mistake & Report t & p-value \\
\hline N_Exchange Int_ & 16,0676 & 6,59381 & 2,437 & $0,0313^{* *}$ \\
\hline N_fin Int & $-9,77856$ & 5,26593 & $-1,857$ & $0,0880^{*}$ \\
\hline Exchange Rate L/\$ & $-0,181833$ & 0,585306 & $-0,3107$ & 0,7614 \\
\hline Exchange Rate L/€ & 0,468544 & 0,590488 & 0,7935 & 0,4429 \\
\hline Immigr. incomes & $-0,468963$ & 0,126320 & $-3,713$ & $0,0030^{* * *}$ \\
\hline Agr_M3 & 0,00185294 & 0,000814842 & 2,274 & $0,0421^{* *}$ \\
\hline R-current & 0,963975 & R-current frame & 0,942960 \\
\hline Test F & 40,13746 & P-value(F) & $1,67 \mathrm{e}-07$ \\
\hline
\end{tabular}

We have profited an important coefficient regarding the immigrants' cash (pvalue: 0,0030). It is almost the same according to our expectancy that a good share of the immigrants' incomes goes to different investments among the Albanian territory. In addition to, we are experiencing pleasing assessments regarding the savings norm, the financial norm along with that of the monetary aggregate M3. All the above mentioned norms are approved by The Central Bank of Albania. Therefore, we could point out the importance of the monetary policy of Albania. The more reliable and matured the policies are the more appealing it becomes to investments. Urged by this motive, we could say that the primary objective of The Central Bank of Albania is to stabilize prices, to get the norm of interest under control and at lower figures. We observe that the exchange rate of lek/euro has a coefficient of positive index but not so important. However, we could not exclude the contribution of this parameter to the explanation of FDI.

\subsection{FDI and the fiscal policies}

$F D I=\alpha+\beta_{1} P_{\text {Tax }}+\beta_{2} \Delta_{\text {Fisc }_{\text {Irom }}}+\beta_{3}$ Corrupt $.+\beta_{4} \mathrm{P}_{\text {Power }}+\beta_{5}$ Technical $_{\text {Govern }}+\varepsilon$

\section{Table 1.5}

\begin{tabular}{|c|c|c|c|c|}
\hline \multicolumn{5}{|c|}{$\begin{array}{c}\text { Model 4: OLS, based on observations 1990-2009 (T = 20) } \\
\text { Depending variable: FDI }\end{array}$} \\
\hline & Coefficient & Standard mistake & Report t & $p$-value \\
\hline Const & $-6,78967$ & 68,1833 & $-0,09958$ & 0,9229 \\
\hline Profit tax & 0,0125781 & 0,00273034 & 4,607 & $0,0013 * * \star$ \\
\hline$\Delta$ _Fisc Incomes & 0,00203349 & 0,000710152 & 2,863 & 0,0187 * \\
\hline Corruption & $-0,645295$ & 10,3508 & $-0,06234$ & 0,9517 \\
\hline Party_Power & 20,2159 & 33,0716 & 0,6113 & 0,5561 \\
\hline Technical governm & 36,1908 & 65,3412 & 0,5539 & 0,5932 \\
\hline R-current & 0,868572 & R-current fra & & 0,795557 \\
\hline$F(5,9)$ & 11,89576 & P-value(F & & 0,000944 \\
\hline
\end{tabular}

At the above mentioned model, we are mainly trying to find out the reason why The Ministry of Finance in Albania is seeking with all possible means to bring Albania close to "the fiscal paradise" with very low taxes with the aim of increasing the number of foreign investors in Albania.

This philosophy is proved at model 4, where we are given a better index concerning the Profit Tax, a low tax if we compare it with our neighbouring countries. It is also one of the most important taxes regarding FDI. Besides, there are encouraging figures concerning the differences at fiscal incomes compared with the previous year. It results from the fact that increasing the state incomes means providing more opportunities to encourage the foreign investments. Worth mentioning about this model is corruption which according to International Institutions influences negatively on FDI.

At the above model we notice that corruption is not an important index although the coefficient is negative.

At this model we decided to have two variables dummy; the party in power and the second the technical government of 1997. We referred to the last ones because we lack the data of 1997 . We did not find a reliable conclusion. We notice at the above model that $\mathrm{R}^{2}$ has got a relatively high value which shows that this model is very reliable. 


\section{Foreing Investments in Albania}

The last model we are going to take into consideration is a model with sustainable effects counting the most important economic figures.

$$
F D I=\alpha+\beta_{1} \Delta_{M_{3}}+\beta_{2} \text { Corruption }+\beta_{3} \mathrm{P}_{\text {Power }}+\beta_{4} I n c_{G D P}++\beta_{5} N_{\text {Exch } h_{\text {Inerest }}}+\mathcal{E}
$$

Table. 1.6

\begin{tabular}{|c|c|c|c|c|}
\hline \multicolumn{5}{|c|}{$\begin{array}{c}\text { Model 5: OLS, based on observations 1993-2009 (T = 17) } \\
\text { Depending variable: FDI } \\
\text { Perfect correlation Dis_VI Dis_GJ }\end{array}$} \\
\hline & Coefficient & Standard mistake & Report t & p-value \\
\hline & 832,560 & 778,961 & 1,069 & 0,3971 \\
\hline Const & 18,0759 & 5,07832 & 3,559 & $0,0707^{*}$ \\
\hline N_Exch_Interest & 0,00227894 & 0,000594502 & 3,833 & $0,0618^{*}$ \\
\hline Agr_M3 & 1228,90 & 405,013 & 3,034 & $0,0936^{*}$ \\
\hline Inc_GDP & 20,2159 & 33,0716 & 0,6113 & 0,1561 \\
\hline Party_Power & 1,30483 & 15,3490 & 0,08501 & 0,9400 \\
\hline Corruption & 11,89576 & P-value(F) & & 0,000944 \\
\hline F (5,9) & 0,998619 & R-current frame & 0,988949 \\
\hline R-current &
\end{tabular}

The only novelty of this model is that we have a very small value ( $p$-value) of the variable party in power. During the last years, the Democratic Party which came in power in 2005 has always asked to increase the flow of FDI in Albania. It is easily understood if we analyse the fiscal reforms after 2005. Besides, we have progress even with the variable AM3 which gives the difference value of monetary aggregate of $\mathrm{M} 3$ in relation to the last year. It shows the credibility of The Central Bank of Albania

We are given $\mathrm{R}^{2}$ with a close value to 1 at this model. On one hand, it proves the reliability of this model but on the other we could say that this model has got simply 17 observations which is less than other observations.

\section{Conclusions}

At this study, the analyse confirms the important role of the monetary and fiscal policy to attract foreign investments in Albania aiming to serve the economic growth.

Based on economic results, we easily observe the dependency of foreign investments on profit tax, on immigrants' shares, on interest norm and on the monetary aggregate M3. not felt.

We observe a concentration of FDI close to borders, even though when we use the data on a regional scale it is

The most unexpected result is that no important index exists between FDI and corruption. This result is against the reports of International Institutions even though the missions of European Union and the International Monetary Fund do never speak their minds about the corruption which prevails in the Albanian political class, but they state that the government could better the fight against corruption.

In summarising this piece of work, we could highlight that monetary and fiscal policies are important instruments to attract foreign investments.

\section{References}

Anthony.C e Ross e Patrick. S. (1998), Albania's economy in transition and turmoil, 1990-97, Ashgate Publishing Company, Brookfield. Bank of Albania (1998), Economic bulletin.

Bank of Albania (2001), Regolamento "Sul credito giornaliero", Edizione Ufficiale, Volume 3, Numero 1, Gennaio 2001.

Bank of Albania (2001), Regolamento "Sul credito Lombard".

Bank of Albania (2003), Piano di sviluppo di medio periodo 2003-2005.

Bank of Albania (2006), Inflation Targeting. tavola rotonda, Tirana, 7-8 dicembre 2006.

Bank of Albania (2008), Documento della politica monetaria.

Bank of Albania (2008), Documento di politica monetaria della Banca d'Albania. il primo semestre del 2008.

Bank of Albania (2008), Regolamento "Sulla riserva minima obbligatoria” Disposizione nr. 43 del 16/07/2008. 
Bank of Albania (2009), Documento di politica monetaria della Banca d'Albania. Terzo semestre del 2009.

Barba Navaretti G. e Venables A. (2006), Le multinazionali nell'economia mondiale. Mulino.

Batt.J (2002), Region, State and Identity in Central and Eastern Europe. Frank Cass.

Bogdani.M (2004), Albania and the European Union. European Integration and the Prospect of Accession. Shtepia e librit shkollor.

Buckley.P. J. e Casson. M.( 1976), The Future of the Multinational Enterprise. Macmillan.

Civici.A. (2009), /l globalismo. Toena.

Daniel. J. Mitchell (2008), Albania Joins the Flat Tax Club, blog cato.org.

Dhori. K. (2007), Politica economica albanese. Toena.

Fischer, Stanley, SAHAY, Ratna e VEGH, Carlos A,. "Stabilization and Growth in Transition Economies: The Early Experience," Journal of Economic Perspectives, 1996.

FMI (2004), Albanian business and investment strategy.

FMI (2006), Albania: selected issue.

FMI (2008), Rapporto per Albania.

FMI, CHRIS.J (1999). "The Rise and Fall of the Pyramid Schemes in Albania".

Gjokutaj. E (2009), Will a new tax structure likely endure.

Gjokutaj.E (2009), Trust, Tax Morale and Corruption.

Gjokutaj.E (2009), Value Added Tax Developments in Albania.

Gjokutaj.E (2010), Legislation on Freezing of Assets and Its Implementation by Tax Office.

Hall.D.(2002)," Albania in Europe: condemned to the periphery or beyond?", in DAWSON, A. H. (edited by), The Changing Geopolitics of Eastern Europe. Frank Cass.

Hymer.S. (1978), The International Operations of National Firms: A. Study of Direct Foreign Investment in "Le Imprese Multinazionali", Einaudi.

ICE (2003), Rapporti Paese congiunti primo semestre.

Maria. F. P (2006), Albania, Esperienze internazionali. Mulino.

Mete (2009), Rapporto Annuale.

USAID (2005), La corruzione in Albania percezioni e esperienze, riassunto dei risultati.

Venetike.N e KICO.Z (2006), Foreign direct investment. The promoter of growth in the Albanian economy.

World Bank (2001), SKREB,M, Monetary Policy Instruments and Monetary Policy Implementation in Albania.

World Bank (2004), Rapporto per l'Albania.

World Bank (2006), Doing business.

World Bank (2007), Doing business.

World Bank (2008), Doing business.

World Bank (2009), Doing business.

World Bank (2010), Doing business.

World Bank(2005), Transnational Corporations and the Internationalization of R\&D. 